\title{
Genetic Mutation Detection of IL-4 Gene in Patients with Atopic Dermatitis in Iraq Population
}

\author{
Aseel Kasim Kareem ${ }^{1}$, Alaa Jawad Hassan ${ }^{2}$ \\ ${ }^{1}$ Lecturer, Department of Biology, College of Science, University of Babylon, Iraq, \\ ${ }^{2}$ Prof. Dr., Department of Biology, College of Science, University of Babylon, Iraq
}

\begin{abstract}
The aim of this study is to detect mutation in IL4 gene in atopic dermatitis patients in Babylon province, Iraq. The current study was performed on (50) Samples of patients with atopic dermatitis and 40 samples represents healthy subjects as control group, their ages ranged between 1-20 years old. The results of the PCR, with newly designed primers, showed 502bp amplicon as well as there were no mutations detected in nucleotide sequences for all samples including control. Therefore, when compare the results of identity for any isolate; it was appeared that there are no differences in nucleotides sequences and atopic dermatitis is not necessarily associated with IL4 gene mutation.
\end{abstract}

Keywords: IL4 gene, atopic dermatitis, PCR, sequensing.

\section{Introduction}

As a common chronic skin disease, atopic dermatitis (AD) affects over $20 \%$ of children with stress and economic impact on the family ${ }^{1,2}$. The first step in the prevention and treatment is to investigate the etiological factors of $\mathrm{AD}$ because it has multifactorial mechanisms including personal and environmental factors like food and environmental allergens as strong factors during youngest age $^{3}$. Polymorphisms of various immune pathway genes are associated with an increased risk of AD through alternations in the T-helper type 2 signaling pathway. ${ }^{4}$ Up regulation of certain interleukin (IL4 and IL-13) lowers FLG expression, which leads to skin barrier defects, furthermore, a gain of functional polymorphisms of Th 2 cytokine receptors IL-4R and IL-13R are also implicated in AD pathogenesis ${ }^{5,6}$. Additionally, the expression/immune expression level of IL-4 is functionally dependent on genetic variants

\section{Corresponding Author:}

Alaa Jawad Hassan

Department of Biology, College of Science, University of Babylon, Iraq

e-mail: alnajaralaa71@gmail.com of IL-4 (SNP). In light of the association studies, it can be hypothesized that some IL-4 SNPs may lead to an overexpression of IL-4 gene and thus influence the immunological reaction ${ }^{7}$. Therefore, the aim of current study was to determine the association between IL4 gene mutation and $\mathrm{AD}$.

\section{Materials and Method}

Collection of blood samples: About $2 \mathrm{ml}$ of venous blood was collected directly in EDTA tubes from 50 patients with $\mathrm{AD}$ and 40 healthy persons.

DNA extraction and purification: DNA was extracted from patients and control individuals using genomic DNA extraction blood DNA Mini Kit (Favorgene, Korea). The DNA concentration and purity at 260/280 nm were measured using Nano Drop spectrophotometer (OPTIZEN POP, Korea). DNA was stored at $-20^{\circ} \mathrm{C}$ till use.

Primer design and PCR: PCR Primer (F: 5'-GAAACCTCAGAATAGACCTACC-3') and (R: 5'-TGTCCTGTGAAATCAGACC-3') were designed from the sequences reported (GenBank accession No. BC022894.1) in order to amplify a 502bp fragment of the IL4 gene. The PCR reaction consisted of $5 \mu \mathrm{l}$ DNA, $12.5 \mu 1$ 1X Master Mix (Promega), $2 \mu 1$ of $10 \mathrm{pmol}$ 
of each specific primer (Macrogen, Korea) and the volume completed to $25 \mu \mathrm{l}$ by DNase free water. The PCR reaction was performed according to conditions mentioned in Table (1).

Electrophoreses was accomplished using 1.5\% agarose gel, stained with ethidium bromide, for $45 \mathrm{~min}$ at 75 volt then, viewed by UV transilluminator and photographed.

DNA sequencing: Sequence similarity was accomplished using the forward primer previously designed through sequence alignment using BLASTN 2.2.27+ program $^{8}$.

\section{Results}

The results show that the presence of a single band (502bp) of the target sequence of IL4 gene (Fig. 1). The sequencing data for samples that takes from the same product of PCR were revealed the heterozygous among patients in location $\mathbf{- 1 1 9 0 3}$ of the samples A5 \& A8 (TC), whenever the risk factor is $\mathbf{C}$ allele for the disease, but for the samples A7 \& A9 the homozygous were (TT) as shown in Table (2) and Figure (2).

Also The results of samples for product of PCR amplification that sent to Sequencing reading appeared the frameshift mutation (deletion) of thymine base in location -12259 in regulatory area of IL4 gene and this mutation is recorded in the NCBI data base with accession number as shown in Figure (3). From the results, this mutation might have an effect on gene expression level and as a result on disease severity.

Table 1: The cycling condition of IL4 gene

\begin{tabular}{|l|c|c|c|}
\hline Steps & Temperature & Time & No. of Cycles \\
\hline Pre- denaturation & $94^{\circ} \mathrm{C}$ & $1 \mathrm{~min}$ & 1 \\
\cline { 1 - 2 } Denaturation & $94^{\circ} \mathrm{C}$ & $45 \mathrm{sec}$ & \multirow{2}{*}{30} \\
\cline { 1 - 2 } Annealing & $60^{\circ} \mathrm{C}$ & $30 \mathrm{sec}$ & \multirow{2}{*}{30} \\
\cline { 1 - 2 } Extension & $72^{\circ} \mathrm{C}$ & $1 \mathrm{~min}$ & \multirow{2}{*}{$5 \mathrm{~min}$} \\
\cline { 1 - 2 } Final Extension & $72^{\circ} \mathrm{C}$ & \multirow{2}{*}{1} \\
\cline { 1 - 2 } Hold & $4^{\circ} \mathrm{C}$ & & \\
\hline
\end{tabular}

Table 2: Identity of IL4 gene sequences with reference sequence [AF395008.1]

\begin{tabular}{|l|c|c|c|}
\hline Code & Allotype & Query Cover. & Ident. \\
\hline A5 & Heterozygous at position -11903 & $100 \%$ & \multicolumn{2}{c|}{$99 \%$} \\
\hline Frameshiftmutation (deletion) at position -12259 & Homozygous & $100 \%$ & $100 \%$ \\
\hline A7 & Heterozygous at position -11903 & $100 \%$ & $100 \%$ \\
\hline A8 & Homozygous & $100 \%$ & $100 \%$ \\
\hline A9 & & \\
\hline
\end{tabular}

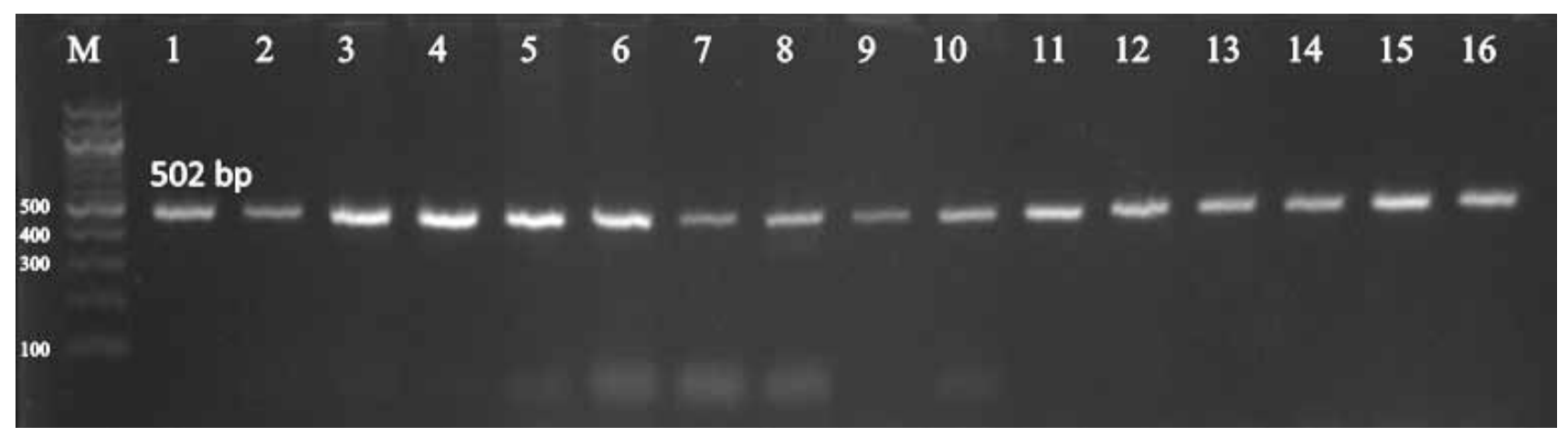

Figure 1: Electrophoresis patterns of PCR product 502bp for IL4 gene loci, lane M DNA 100bp marker, lane 1- 10 PCR product of patient, lane 11-16 PCR product of control, 1.5 \% agarose, $75 \mathrm{~V}, 20$ Am for 45 Minutes. (10 $\mu$ in each well) 


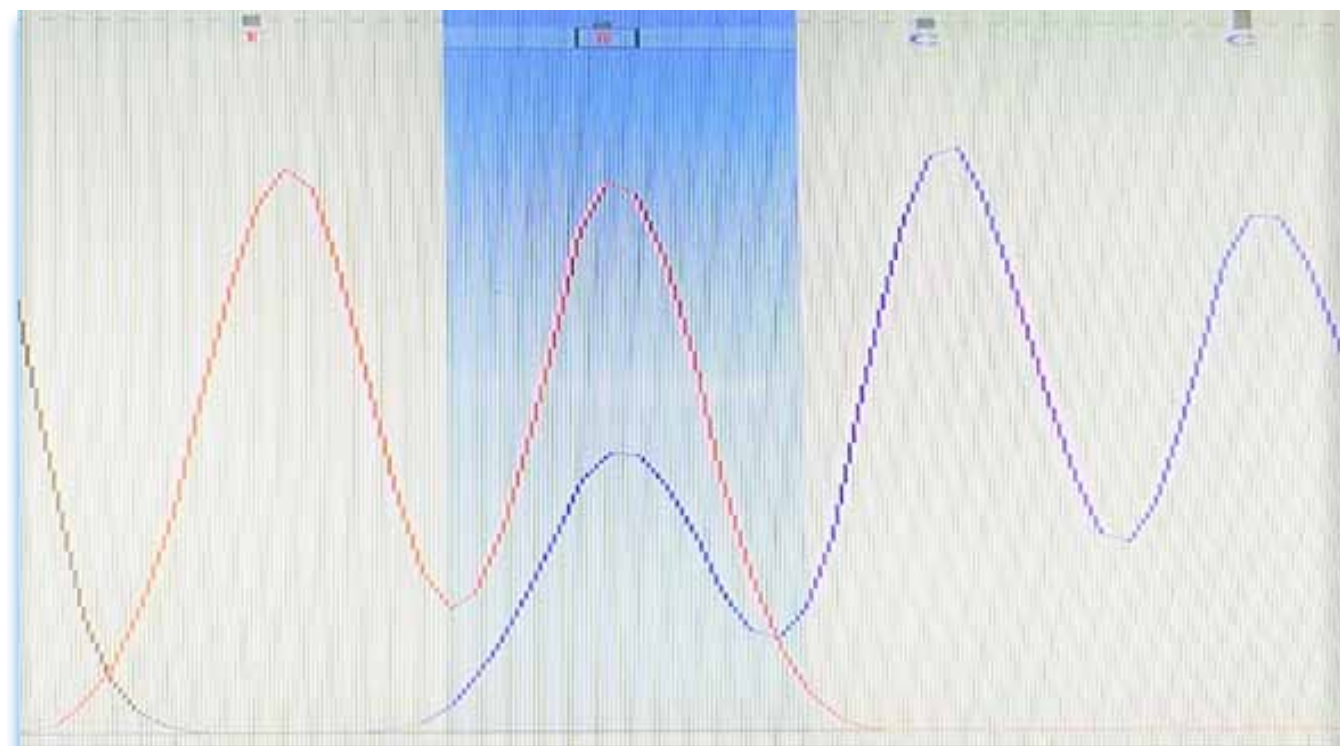

Figure 2: Sequence detection of Heterozygous in regulatory area of IL4 gene TC among patient with AD. Type risk factor: $\mathrm{C}$ allele

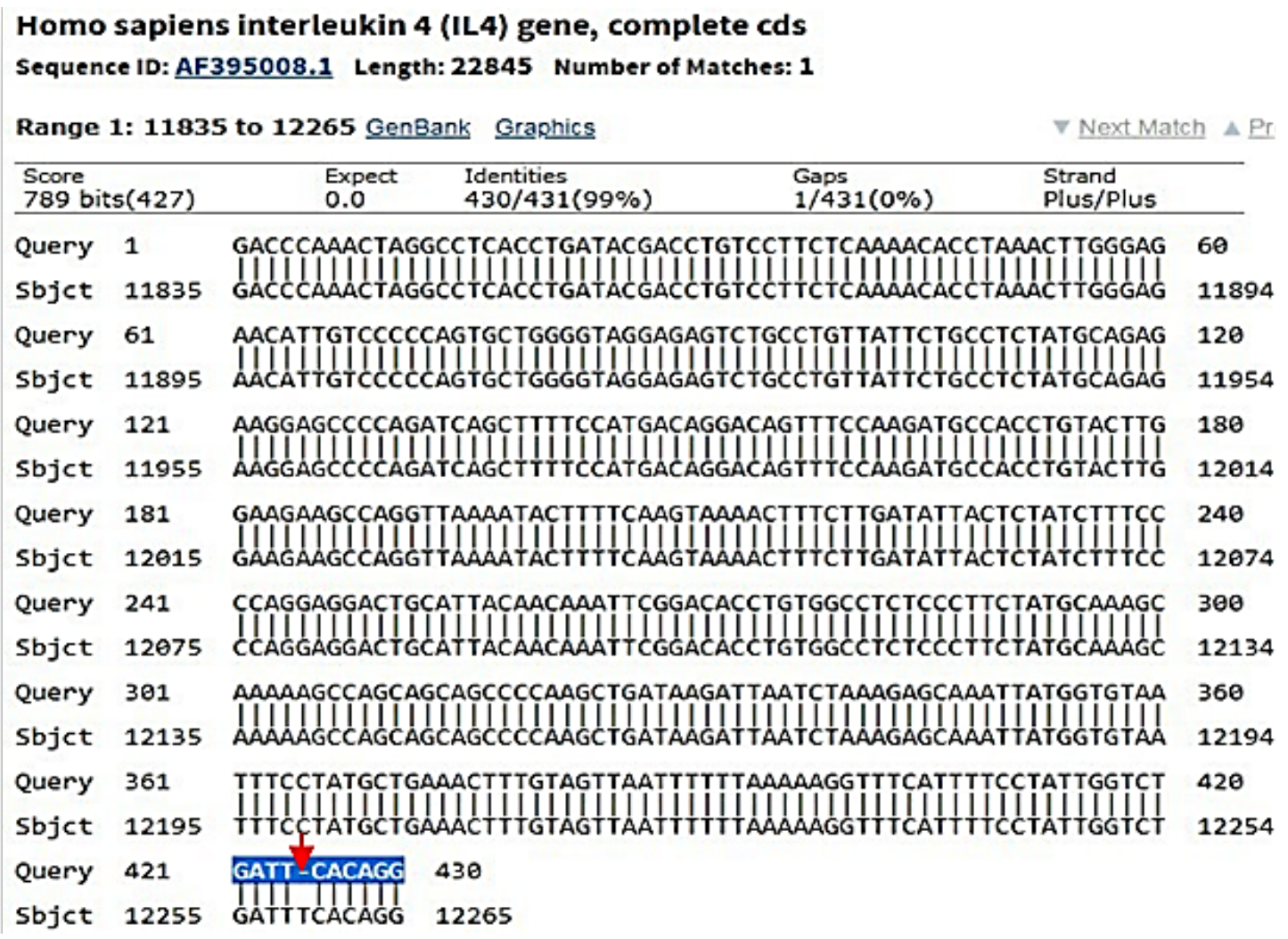

Figure 3: Frameshift mutation (deletion) detected in location -12259 of IL4 gene (Sample A5)

\section{Discussion}

The current study agreement with Malaisse et al,(2014) whom noticed the IL4 promotes that development of atopic diseases through effects on multiple cell types. Despite its critical role in $\mathrm{AD}$, how IL4 alters gene expression in keratinocytes has not been completely defined. In this report its used high-throughput transcriptomicanalysis to identify IL4 induced changes in keratinocytegene expression at early and late stages of differentiation. 
Acute and chronic IL4 stimulation resulted in extensive changes in gene expression profiles that spanned a variety of functional modules, including wound healing, a biological response impaired by IL4 .

The results of heterozygous (TC) for IL4 gene using sequencing technique when the $\mathrm{C}$ allele that represented risk factor for disease disagreement with Zahran et al, (2013) that conclusion, the IL4 gene polymorphism (C-590T) had no relationship with the development of both types of dermatitis, but the $\mathrm{C}$ allele was risk factor for disease.

\section{Conclusion}

There were many mutations detected in nucleotide sequences for all samples including control. Therefore, when compare the results of identity for any sample; it was appeared that there are many differences in nucleotides sequences and atopic dermatitis is necessarily associated with IL4 gene mutation.

Financial Disclosure: There is no financial disclosure.

Conflict of Interest: None to declare.

Ethical Clearance: All experimental protocols were approved under the Department of Biology and all experiments were carried out in accordance with approved guidelines.

\section{References}

1. Barbeau M, Bpharm H L. Burden of atopic dermatitis in Canada. Int J Dermatol. 2006; 45, $31 \mathrm{e} 6$.

2. Flohr C, Mann J. New insights into the epidemiology of childhood atopic dermatitis. Allergy 2014; 69, $3 \mathrm{e} 16$.

3. Kantor R, Silverberg JI. Environmental risk factors and their role in the man-augment of atopic dermatitis. Expert Rev ClinImmunol2017; 13(1):15-26.
4. Kaufman BP, Guttman-Yassky E, Alexis AF. Atopic dermatitis in diverse racial and ethnic groups-Variations in epidemiology, genetics, clinical presentation and treatment. ExpDermatol. 2018; 27:340 -357.

5. Namkung JH, Lee JE, Kim E Association of polymorphisms in genes encoding IL-4, IL-13 and their receptors with atopic dermatitis in a Korean population. Exp Dermatol. 2011; 20:915-919.

6. Hussein YM, Shalaby SM, Nassar A, Alzahrani SS, Alharbi AS, Nouh M Association between genes encoding components of the IL-4/IL-4 receptor pathway and dermatitis in children. Gene.2014; 545:276 - 281 .

7. Kabesch M, Schedel M, Carr D. IL-4/IL-13 pathway genetics strongly influence serum $\operatorname{IgE}$ levels and childhood asthma. Journal of Allergy and Clinical Immunology 2006; 117: 269-274.

8. Zahran F, Yousri M, EsmatA, Magda S. Interleukin-4 and interleukin-4 receptor alpha polymorphisms in atopic dermatitis: A case-control study Bio Chemistry:An Indian Journal 2013;1902-2013.

9. Bogiatzi S I, Fernandez I, Bichet J C, MarloieProvost $\mathrm{M}$ A and Volpe E.Cutting Edge: Proinflammatory and $\mathrm{Th} 2$ cytokines synergize to induce thymic stromal lymphopoietin production by human skin keratinocytes. J Immunol. 2007; 178, 3373-3377.

10. De Benedetto A, Rafaels NM, McGirt LY, Ivanov AI, Georas SN, Cheadle C. Tight junction defects in patients with atopic dermatitis. J Allergy ClinImmunol. 2011; 127:773-86.

11. Malaisse J, Bourguignon V, De Vuyst E, Lambert de Rouvroit C, Nikkels AF, Flamion B. Hyaluronan metabolism in human keratinocytes and atopic dermatitis skin is driven by a balance of hyaluronan synthases 1 and 3. J Invest Dermatol 2014; 134: 2174-82. 